\title{
RESULTS OF POSTERIOR MYECTOMY FOR THE TREATMENT OF CHILDREN WITH CHRONIC CONSTIPATION
}

\author{
Mehran PEYVASTEH ${ }^{1}$, Shahnam ASKARPOUR ${ }^{1}$, Abdol-Hassan TALAIEZADEH ${ }^{1}$, \\ Mohammad-Reza IMANI ${ }^{1}$ and Hazhir JAVAHERIZADEH ${ }^{2}$
}

Received 29/4/2015

Accepted 16/6/2015

\begin{abstract}
Background and Objectives - The aim of this study was to evaluate the result of posterior myectomy in children with chronic constipation who underwent to this surgery. Methods - Forty eight children with chronic constipation who did not respond to diet, laxative, or enema were included. Children with abnormal barium enema showing transitional zone were excluded. Children with documented metabolic disease diabetes, and hypothyroidism were also excluded. All patients underwent posterior myectomy. Children were followed during 1 year after surgery regarding frequency of fecal evacuation, fecal consistency, straining during defecation, and diameter of feces. Data was analyzed using SPSS version 13.0 (Chicago, IL, USA). Results - Of 48 cases that underwent surgery, 21 were male and 27 were female. Age range was 1.5 to 11 years old. Mean duration of constipation before surgery was $22.79 \pm 17.08$ (range 6-48 months). Mean duration of medical treatment was $14.90 \pm 10.31$ (range $=6-48$ months). Fecal consistency, feces diameter, number of bowel movements and straining during defecation were compared before and after surgery. The results were statistically significant $(P<0.001)$. Of all cases, $52 \%$ continued treatment of constipation after surgery for 1 year. Ganglion cells were absent in 32 cases. Ganglion cells were present in seven children. Proximal ganglion cell was found in nine cases Treatment response was not different between cases according to status of ganglion cell in biopsy. Conclusion - Fecal consistency, feces diameter, number of bowel movements, and straining for defecation were improved after posterior myectomy. Another study with more sample is required for better evaluation of treatment.
\end{abstract}

HEADINGS - Anal canal. Constipation. Fecal incontinence. Hirschsprung disease.

\section{INTRODUCTION}

Anorectal myectomy or internal anal sphincterotomy was first described for diagnosis and treatment of short segment Hirschsprung's disease ${ }^{(2,12)}$. Eight years later, Martelli et al. used anorectal myectomy for the treatment of idiopathic constipation ${ }^{(10)}$. Posterior internal sphincter myectomy (ISM) has been recommended as the treatment of choice for patients with ultrashort Hirschsprung's disease and internal anal sphincter achalasia $^{(2,5)}$.

The aim of this study was to evaluate results of anorectal myectomy in children with refractory constipation who were referred to our hospital for anorectal myectomy.

\section{METHODS}

This prospective study was done on 48 children who did not respond to medical treatment of constipation by pediatric gastroenterologist and general pediatrician. These children were completely evaluated by pediatric gastroenterologists regarding causes of constipation by anorectal manometry, unprepared barium enema for Hirschsprung's disease, hypothyroidism, and celiac disease. Digital rectal examination was done for all cases. Inclusion criteria was children with refractory chronic constipation who followed treatment for constipation. Exclusion criteria was contraindication for surgery and anesthesia and response to medical treatment for constipation. Patients with classical transition zone, evidence of hypothyroidism, celiac disease were also excluded. Duration of study was 2 years starting from March 2010. Detail of surgery was discussed with parents and informed consent was signed by them. Age, sex, onset of constipation, number of defecation per day, straining during defecation, and diameter of defecation were recorded. Barium enema was done for all subjects and were normal. Then, patients underwent to posterior myectomy. Duration of follow up was one year after surgery. Number of defecation, fecal

\footnotetext{
Declared conflict of interest of all authors: none Disclosure of funding: no funding received

Department of Surgery, Imam Khomeini Hospital, Ahvaz Jundishapur University of Medical Sciences, Ahvaz, Iran; ${ }^{2}$ Department of Pediatrics, Abouzar Children's Hospital, Ahvaz Jundishapur University of Medical Sciences, Ahvaz, Iran.

Correspondence: Shahnam Askarpour. Prof. of Pediatric Surgery, Department of Surgery, Imam Khomeini Hospital, Ahvaz Jundishapur University of Medical Sciences,
} Ahvaz, Iran. E-mail: shahnam_askarpour@yahoo.com 
consistency, straining, and diameter of feces were recorded after treatment. Stool consistency was defined as a normal (semi loose) and hard according to subjective report by parents or child. Diameter of feces was defined as large diameter (or with fecal soiling) versus normal diameter (or without fecal soiling) according to subjective reports by parents or child. Bristol stool chart was used for evaluation of type of $\operatorname{stool}^{(9)}$. Normal frequency of defecation was defined as one defecation per 3 days. One defecation per 4 days or more was considered abnormal. Data was analyzed using SPSS version 13.0 (Chicago, IL, USA).

\section{Technique of surgery}

Bowel preparation was done before surgery. Under general anesthesia, in lithothomy position an anal speculum was used to stretch the posterior wall. Anal canal was opened by finger. A small transverse incision was made at 6 O' clock position. Submucosal dissection was performed. Dissection of the internal sphincter was performed in the intersphincteric plane. The incision was extended proximally to include the rectal muscle for $5 \mathrm{~cm}$ or till the dilated part of the rectum was reached. Submucosal flap was elevated using silk. Myectomy with $0.5-1 \mathrm{~cm}$ size was performed on full thickness muscle layer. Length of resected muscle should be at least $5 \mathrm{~cm}$. Proximal and distal ends were marked and sent for frozen section (Figure 1).

\section{RESULTS}

In this study, 48 children $($ male $=21$, female $=27$ ) who underwent posterior myectomy were included. Mean age of the cases was $4.41 \pm 2.58$ ranged 1.5-11 years old. Mean duration of constipation was $22.79 \pm 17.08$ ranged 6-48 months. Duration of medical treatment for constipation was $14.90 \pm 10.31$ (ranged 6-48 months). Patients were followed for 1 year after surgery. Stool consistency was hard in 48 cases before surgery. According to Bristol chart, type 1-2 was seen in most of the

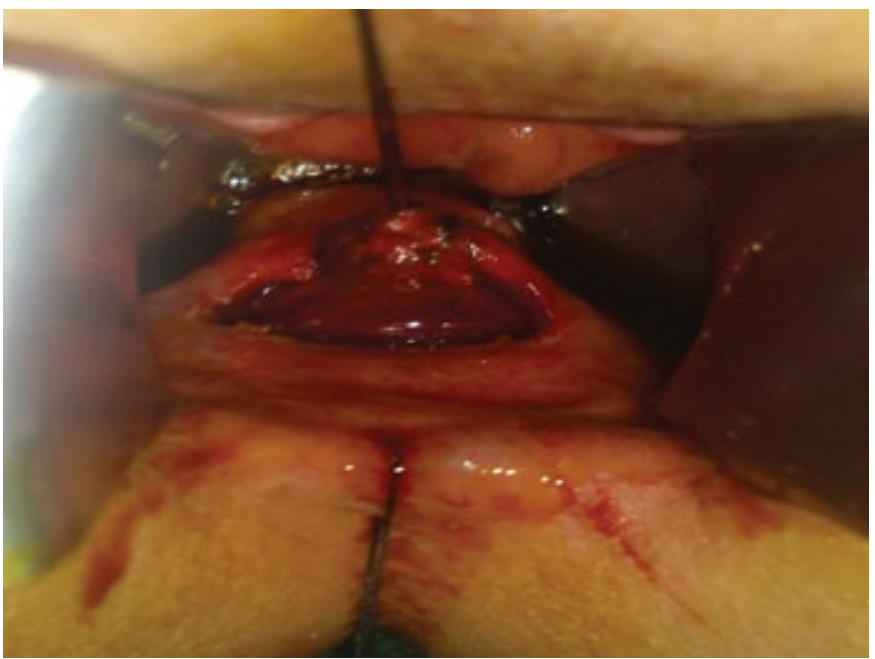

FIGURE 1. Posterior rectal myectomy cases before myectomy. Stool consistency was semi loose in 44 cases after surgery (hard stool was reported by 4 cases) $(P<0.001)$. Most of the cases after surgery had stool type 3 and 4 according to Bristol classification. Fecal diameter was large in 48 cases before surgery versus 6 cases after surgery $(P<0.001)$ (Table 1). Straining behavior was significantly improved following surgery $(P<0.001)$ (Table 1$)$ Frequency of defecation was abnormal in 46 cases before surgery versus 3 cases after surgery $(P<0.001)$ (Table 1$)$. Fecal defecation was improved in $45(93.7 \%)$ of cases. Improvement in force was noticed in $46(95.8 \%)$ of subjects. Fecal softening was found in $44(91.7 \%)$ of surgery. Ganglion cell was present in $7(14.6 \%)$ child. In $32(66.7 \%)$ cases, ganglion cell was absent. Proximal ganglion cell was present in $9(18.8 \%)$ cases.

Of seven cases with present of ganglion cell, $7(100 \%)$ subjects showed improvement in fecal diameter and also consistency. Defecation improved in $6(85.71 \%)$ cases. Of 32 cases with absent ganglion cell, $30(93.75 \%)$ cases showed improved defecation. Of 32 , improvement in fecal diameter and consistency was observed in $28(87.5 \%)$ and $29(90.6 \%)$ cases respectively. There was no significant difference between treatment response in terms of absence or presence of ganglion (Table 2).

Of nine cases with proximal ganglion cell, $100 \%$ of subjects showed improved defecation. Fecal diameter and consistency were improved in seven and eight cases respectively. Of all cases, $52 \%$ required post operation treatment of constipation. Fecal incontinency was not observed during the follow up period.

TABLE 1. Fecal consistency, fecal diameter, and frequency of defecation in patients

\begin{tabular}{lccc}
\hline & $\begin{array}{c}\text { Before } \\
\text { myectomy }\end{array}$ & $\begin{array}{c}\text { After } \\
\text { myectomy }\end{array}$ & P value \\
\hline Fecal consistency & $\begin{array}{c}\text { Soft: } 0 \\
\text { Hard: } 48\end{array}$ & $\begin{array}{c}\text { Soft: } 44 \\
\text { Hard: } 4\end{array}$ & $<0.001$ \\
& Normal:0 & Normal: 42 & \\
Fecal diameter & Large: 48 & Large: 6 & $<0.001$ \\
& Yes: 46 & Yes:2 & \\
Straining & No:2 & No: 46 & $<0.001$ \\
Frequency of Defecation & Normal: 2 & Normal:45 & \\
$\begin{array}{l}\text { Normal: } 1 \text { defecation/3days } \\
\text { Abnormal: } 1 \text { defecation }\end{array}$ & Abnormal: 46 & Abnormal:3 & $<0.001$ \\
$>4$ days & & & \\
\hline
\end{tabular}

TABLE 2. Improvement in fecal diameter, fecal consistency, and frequency of defecation in patients regarding to absent or present ganglion cell

\begin{tabular}{cccccc}
\hline & $\begin{array}{c}\text { Proximal } \\
\text { ganglion } \\
\text { cell }\end{array}$ & $\begin{array}{c}\text { Distal } \\
\text { ganglion } \\
\text { cell }\end{array}$ & $\begin{array}{c}\text { Improved } \\
\text { fecal } \\
\text { diameter }\end{array}$ & $\begin{array}{c}\text { Improved } \\
\text { fecal } \\
\text { consistency }\end{array}$ & $\begin{array}{c}\text { Improved } \\
\text { frequency of } \\
\text { defecation }\end{array}$ \\
\hline $\mathrm{n}=7$ & Present & Present & $7(100 \%)$ & $7(100 \%)$ & $6(85.71 \%)$ \\
$\mathrm{n}=32$ & Absent & Absent & $28(87.5 \%)$ & $29(90.62)$ & $30(93.75 \%)$ \\
$\mathrm{n}=9$ & Present & Absent & $7(77.78 \%)$ & $8(88.88 \%)$ & $9(100 \%)$ \\
& & & $\begin{array}{c}\mathrm{Chi}^{2}=0.12 \\
P=0.94\end{array}$ & $\begin{array}{c}\mathrm{Chi}^{2}=0.03 \\
P=0.98\end{array}$ & $\begin{array}{c}\mathrm{Chi}^{2}=0.04 \\
P=0.97\end{array}$ \\
\hline
\end{tabular}




\section{DISCUSSION AND CONCLUSION}

Bently et al. reported posterior exicisional anorectal myectomy in the management of chronic fecal accumulation ${ }^{(1)}$. In this study, $85 \%-100 \%$ of cases with different pathology, showed improvement after posterior myectomy. Redkar et al. in their study on 28 children age 11 months to 9 years showed anorectal myectomy had $93 \%$ good response. Duration of follow up was 6 months to 5 years ${ }^{(14)}$.

In this study the mean time of treatment before myectomy was $14.90 \pm 10.31$ (ranged 6-48 months) which was significantly higher than Redkar et al study ${ }^{(14)}$ which 1 month was considered for refractory constipation. In the study by Mousavi et al., mean duration of constipation before treatment was 28.4 months (range:3-71 months) ${ }^{(11)}$.

Wildhaber et al. studied results of posterior myectomy in children with Hirschsprung's disease. About $60 \%$ of patients showed good response to treatment ${ }^{(19)}$. De Calwue et al. reported beneficial effect of internal sphincter myectomy for the treatment of sphincter achalasia ${ }^{(2)}$. In the study by Mousavi et al., improvement was seen in $68.2 \%$ of children with chronic constipation underwent anorectal myectomy ${ }^{(11)}$. In the study by Freeman, $85.7 \%$ of 61 children who had anorectal myectomies had improvement after procedure ${ }^{(4)}$. In the study by Scobie and Mackinlay, normal bowel movements were seen in all children who had underwent myectomy due to ultrashort segment Hirschsprung's disease ${ }^{(17)}$. Result of the present study was similar to Redkar et al. ${ }^{(14)}$ and Free$\operatorname{man}^{(4)}$ studies.

Krivchenia et al. studied effect of rectal myectomy in treatment of chronic constipation. They reported beneficial effect for 22 children $^{(8)}$. In the study by Doodnath and Puri, on 24 patients with internal anal sphincter achalasia, $62.5 \%$ of cases showed regular bowel motions after myectomy ${ }^{(3)}$. In another study, on 15 cases with internal anal sphincter achalasia, seven patients showed regular bowel movement without laxative ${ }^{(2)}$.

Of 32 cases with absent ganglion cell, 90\% showed improvement following myectomy. In the study by Kaymakcioglu et al., they concluded that anorectal posterior myectomy is an effective operation in diagnosis and treatment of short segment Hirschsprung ${ }^{(6)}$. In the study by Ryouichi and Howard, they found that myectomy may cause persistent constipation $^{(15)}$. In the study by Pinho et al., they showed that results of anorectal myectomy were independent of preoperative colonic transit or histological evidence of aganglionosis ${ }^{(13)}$.

In this study ganglion cell was absent in 41 cases, which 9 cases had proximal ganglion cell. In Redkar et al. study, 10 cases had aganglionosis and 5 of them had proximal ganglion cell $^{(14)}$. The rate of absent of ganglion cell was higher than Redkar et al. study. This difference may be due different inclusion criteria. In Redkar et al. study, children with 1 month treatment for constipation that was not responsive were included ${ }^{(14)}$, but in this study, children with failure to 6 months treatment were included.

The present results of posterior myectomy were similar to the other studies, but duration of follow up was less than others. Most of the studies supported the benefit of posterior myectomy in the treatment of chronic constipation ${ }^{(3,6)}$.

Normal pathology was seen in $7(14.58 \%)$ of 48 cases. In Redkar et al. study, $25 \%$ of cases had normal pathological report $^{(14)}$. Normal pathological findings were present in $72.7 \%$ in Mousavi et al. study ${ }^{(11)}$.

Fecal incontinency was not seen during 1 year follow up. In another study, fecal incontinency was not seen after treatment of anal sphincter achalasia using internal sphincter myectomy in 15 patients $^{(2)}$. In the Redkar et al. study on 28 patients, one patient developed transient fecal incontinence which was resolved 6 weeks later. Limitation in sample size or follow up period may be the cause of underestimation of fecal inconsistency after anorectal myectomy.

Anorectal myectomy is a excellent diagnostic and therapeutic procedure for different cause of refractory chronic constipation $^{(7,16,18)}$.

Fecal consistency, feces diameter, number of bowel movements, and straining for defecation were improved after posterior myectomy. Presence or absence of ganglion cell had no significant effect on outcome. It may be appropriate in children who have refractory chronic constipation after appropriate medical treatment and diagnostic workup. Another study with more sample is required for better evaluation of treatment.

\section{Limitation}

The main limitation of this study was the duration of follow up. Standard criteria was not available for fecal diameter. Colonic transit time study was not available in our university hospital.

\section{ACKNOWLEDGMENT}

Data was used in this paper was from residency thesis of Dr. Mohmmad Reza Imani and financial support was provided by research affairs of Ahvaz Jundishapur University of Medical Sciences. Authors would like to thank Mr. Mohammad Hossein Haghighizadeh for statistical analysis.

\section{Authors' contributions}

Peyvasteh M: main idea and supervisor of thesis. Askarpour S: literature search, performing surgery, and writing draft of manuscript. Talaiezadeh AH: data collection and literature search. Imani MR: writing proposal and data collection. Javaherizadeh $\mathrm{H}$ : searching literature and manuscript writing and revision. 
Peyvasteh M, Askarpour S, Talaiezadeh AH, Imani MR, Javaherizadeh H. Resultados da miomectomia posterior em crianças com constipação crônica. Arq Gastroenterol. 2015,52(4):xxx.

RESUMO - Contexto e Objetivo - O objetivo deste estudo foi avaliar o resultado da miectomia posterior em crianças com constipação crônica que se submeteram à cirurgia. Métodos - Quarenta e oito crianças com constipação crônica que não responderam à dieta, laxante ou enema, foram incluídas em nosso estudo. Crianças com enema de bário anormal, mostrando a zona de transição foram excluídas. Crianças com hipotireoidismo, diabetes e doença metabólica documentada também foram excluídas. Os pacientes foram submetidos à miectomia posterior. As crianças foram seguidas durante 1 ano após a cirurgia em relação a frequência de evacuação fecal, consistência fecal, esforço durante a defecação e diâmetro de fezes. Os dados foram analisados usando SPSS versão 13.0 (Chicago, IL, EUA). Resultados - Dos 48 casos submetidos à cirurgia, 21 eram do sexo masculino e 27 eram do sexo feminino. A faixa etária foi de 1,5 a 11 anos de idade. A duração média da constipação antes da cirurgia foi $22.79 \pm 17.08$ (intervalo 6-48 meses). A duração do tratamento médico era 14.90 110.31 (intervalo = 6-48 meses). Consistência fecal, diâmetro das fezes, número de evacuações e esforço durante a defecação, foram comparados antes e depois da cirurgia. Os resultados foram estatisticamente significantes $(P<0.001)$. De todos os casos, $52 \%$ continuaram o tratamento da constipação após a cirurgia por 1 ano. Células ganglionares estavam ausentes em 32 pacientes e estiveram presentes em sete pacientes. Células ganglionares proximais foram encontradas em nove casos. A resposta ao tratamento não foi diferente entre os casos de acordo com a presença ou não de células ganglionares na biópsia. Conclusão - A consistência fecal, o diâmetro das fezes, o número de evacuações e o esforço para defecação, melhoraram após miectomia posterior. Para melhor avaliação do tratamento é necessário outro estudo com uma amostra maior.

DESCRITORES - Canal anal. Constipação intestinal. Incontinência fecal. Doença de Hirschsprung.

\section{REFERENCES}

1. [no authors listed].Seminar on pseudo-hirschsprung's disease and related disorders. Arch Dis Child. 1996; 41(216): 143-54.

2. de Caluwe D, Yoneda A, Akl U, Puri P. Internal anal sphincter achalasia: outcome after internal sphincter myectomy. J Pediatr Surg. 2001;36(5):736-8.

3. Doodnath R, Puri P. Long-term outcome of internal sphincter myectomy in patients with internal anal sphincter achalasia. Pediatr Surg Int. 2009;25(10):869-71.

4. Freeman NV. Intractable constipation in children treated by forceful anal stretch or anorectal myectomy: preliminary communication. J R Soc Med. 1984; 77(Suppl 3):6-8.

5. Heikkinen $\mathrm{M}$, Lindahl $\mathrm{H}$, Rintala RJ. Long-term outcome after internal sphincter myectomy for internal sphincter achalasia. Pediatr Surg Int. 2005;21(2):84-7.

6. Kaymakcioglu N, Yagci G, Can MF, Demiriz M, Peker Y, Akdeniz A. Role of anorectal myectomy in the treatment of short segment hirschsprung's disease in young adults. Int Surg. 2005;90(2):109-12.

7. Krebs C, Acuna R. Transanal internal sphincter myomectomy: indications, operative procedure and results. Eur J Pediatr Surg. 1994;4(3):151-7.

8. Krivchenia D, Lurchenko NI, Almashii GG, Mun VA, Soroka VP. [Rectal myectomy in the treatment of chronic constipation in children]. Klin Khir. 1990(6):24-6.

9. Lewis SJ.Heaton KW. Stool form scale as a useful guide to intestinal transit time. Scand J Gastroenterol. 1997;32(9):920-4.
10. Martelli H, Devroede G, Arhan P, Duguay C. mechanisms of idiopathic constipation: outlet obstruction. Gastroenterology. 1978;75(4):623-31.

11. Mousavi SA, Karami H, Rajabpoor AA. Intractable chronic constipation in children: outcome after anorectal myectomy. Afr J Paediatr Surg. 2014,11(2):147-9.

12. Nissan S, Bar-Maor JA, Levy E. Anorectal myomectomy in the treatment of short segment hirschsprung's disease. Ann Surg. 1969,170(6):969-77.

13. Pinho M, Yoshioka K, Keighley MR. Long-term results of anorectal myectomy for chronic constipation. Dis Colon Rectum. 1990;33(9):795-7.

14. Redkar RG, Mishra PK, Thampi C, Mishra S. Role of rectal myomectomy in refractory chronic constipation. AfrJ Paediatr Surg. 2012;9(3):202-5.

15. Ryouichi T, Howard ER. Assessments of anorectal myectomy for short segment hypoganglionosis in childhood. Hepatogastroenterology. 2007;54(73):91-5.

16. Sawin R, Hatch E, Schaller R, Tapper D. Limited surgery for lower-segment hirschsprung's disease. Arch Surg. 1994;129(9):920-4; discussion 924-5.

17. Scobie WG, Mackinlay GA. Anorectal myectomy in treatment of ultrashort segment hirschsprung's disease. report of 26 cases. Arch Dis Child. 1977;52(9):713-5.

18. Shehata SM, El-banna IA, Gaber AA, El-samongy AM, Attia MA. Longterm evaluation of modified lateral anorectal myomectomy for low-segment hirschsprung disease. Arch Surg. 1998;133(3):269-71.

19. Wildhaber BE, Pakarinen M, Rintala RJ, Coran AG, Teitelbaum DH. Posterior myotomy/myectomy for persistent stooling problems in hirschsprung's disease. J Pediatr Surg. 2004;39(6):920-6; discussion 920-6. 